\title{
Schopenhauer's Metaphilosophy: How to Think a World Without Reason
}

\author{
Sebastian Gardner
}

I suggested in a previous paper that Schopenhauer's decision to focus his doctoral dissertation on the Principle of Sufficient Reason owes a great deal to his opposition to Fichte, Schelling, and Hegel. The thesis concerning the limits of thought advanced in Fourfold Root, though effective in undermining the speculative idealism of his post-Kantian contemporaries, is however both problematic on its own account and directly responsible for well known difficulties facing Schopenhauer's metaphysics of will. The relation of Fourfold Root to The World as Will and Representation is thus ambiguous, for while it prepares the way for Schopenhauer's reinstatement of Kant's transcendental idealism as he understands it, it at the same time obstructs a literal metaphysical reading of his identification of world with Wille. In response I offer, first, an account of the historical context which helps to make sense of Schopenhauer's metaphilosophical decisions, and second, a construal of Schopenhauer's metaphilosophy designed to protect his claim to offer a coherent alternative to rationalist forms of post-Kantian idealism (though not his claim to have undermined or surpassed them).

\section{I.}

When we look back at Fourfold Root from the standpoint of The World as Will and Representation, as Schopenhauer tells us to do in the latter's Preface (WWR 1, 7 [ix-x]), the claims of the earlier work are readily intelligible: Fourfold Root spells out a number of key theses, elaborated at length in $W W R$, concerning the structure and limits of human knowledge and the different types of objects and relations corresponding to its different ordering principles. ${ }^{1}$ Whether it also offers support for those theses in addition to what is argued in $W W R$, as Schopenhauer leads us to expect, ${ }^{2}$ is more doubtful, but Schopenhauer clearly has good reason to describe Fourfold Root as an effective introduction to $W W R$.

Considered in isolation from the later work, what is most striking about Fourfold Root - and what, from the evidence of reviews, puzzled its readers in $1813^{3}$ - is that Schopenhauer appears to resurrect a principle with a long and distinguished history in early modern rationalism which he at the same time regards Kant as having disposed of. If Kant has stripped the PSR of its former authority as an epistemological principle and tool of metaphysical enquiry, what then is the point of revalidating it? Why not instead offer the principle as a revised version of Kant's principles of the 
understanding? Given that the new principle is so unlike the old - the mere husk of it, in effect ${ }^{4}-$ there seems little point in re-employing the old title. One of the chief implications of Schopenhauer's critical discussion of the use made of the PSR by pre-Kantian philosophers is that a good number of central arguments in the rationalist tradition can be charged with confusing different senses of ground or reason, ${ }^{5}$ but this hardly required a new theory of the PSR, and in any case all of the relevant work in support of this verdict had been done already by Kant. ${ }^{6}$ In fact not even the Critical philosophy was required for this: Kant's very early New Elucidation (1755), following Crusius, had already sharply discriminated logical from real grounds, and Euler had made the key anti-Wolffian point that the substantial issue is not the PSR itself but whether or not we have the capacity to use it to generate explanations and render things like corporeality intelligible. Leibnizians, according to Euler, have confused the truth of the principle with our capacity to employ it to positive ends. ${ }^{7}$

It is true that Schopenhauer's claims concerning the structure of human cognition in Fourfold Root do not merely repeat Kant but include vital disagreements with him, and that postulation of the PSR as a single principle at work across the board in human cognition is of assistance to Schopenhauer, in so far as it makes it easier for him to set causality on a par with space and time, and to assimilate practical reason to a sub-form of theoretical reason, thereby dismantling key pieces of Kant's architecture. But these purposes would have been served just as well if not better by advertising his work as an innovative reformulation of transcendental idealism and the Kantian system as a whole - which is how he, in effect, presents his position in Book 1 and the Appendix of $W W R$ respectively. The puzzle, in short, is why Schopenhauer should offer what is actually a study in the history of metaphysics as seen through the lens of the Critical Philosophy, followed by a set of revisions to Kant, as the correct account of a principle still associated firmly, in 1813, with the Wolffian philosophy that Kant had, in Schopenhauer's own view, rendered metaphysically impotent.

The answer to this puzzle lies, I suggest, in Schopenhauer's antagonism towards the German Idealists, ${ }^{8}$ whom he perceives as the modern incarnation of the malign optimistic tendency in Western thought, and that his aim in Fourfold Root is to reinstate in clarified and purged form Kant's original insights, as he understands them. The main points in this account of Schopenhauer's reasons for focussing on the PSR can be summarized under three interconnected headings:

Schopenhauer's distinctive metaphilosophical position; his absorption of one key idea that he takes from the German Idealists, concerning the proper way to develop Kant's philosophy; and his intention of undercutting at its root the Fichte-Schelling-Hegel development. ${ }^{9}$

1. Minimalist metaphilosophy in Fourfold Root. I raised the question of whether Schopenhauer is justified in regarding Fourfold Root as providing support for the relevant key 
theses of WWR. Whether it does so depends of course on what counts as support, and if our expectation is of finding in Fourfold Root transcendental arguments of a Kantian or Fichtean sort, or even just a Prolegomena-style regressive argument, then we will be disappointed: in $\S 14$ Schopenhauer explicitly rejects as fruitless, circular, and absurd all attempts to prove PSR. His alternative to Kant's proof of the causal principle, for example, is mere asseveration of 'the unshakeable certainty' of our convictions concerning the future course of experience $(F R, 86[89])$.

What needs to be taken on board - in order for Schopenhauer's position in WWR not to seem unaccountably dogmatic or peculiarly naive - is Schopenhauer's ab initio commitment to an ultraminimal account of synthetic a priori knowledge. ${ }^{10}$ I will come back to this shortly, but the point to emphasize for now is that by redescribing principles that Kant would have regarded as in need of and as capable of being provided with deductions, as forms of the PSR, Schopenhauer signals his view that it is a mistake to even contemplate equipping them with any sort of justification: just as the PSR in the eyes of the rationalists is epistemically final - justified by its being simply constitutive of ideation and knowledge - so too, Schopenhauer is indicating, are his four principles. The absence of justification is no deficiency because to refuse to acknowledge their validity is, for Schopenhauer, a bootless attempt to blind oneself to what is immediately subjectively certain, and to require more, in Schopenhauer's view, is to demand the transcendent perspective on our cognition that Kant rightly denies us. Kant's use of the table of judgements to give a higher, noncontingent status to the categories is in this light incoherent: by his own account, Kant is missing the necessary external authorization. ${ }^{11}$

2. Reduction of reason to the transcendental. The idea which Schopenhauer takes from Fichte and the early Schelling is that the limits of reason or the thinkable, and the limits of cognition or knowable truth, should be understood to coincide, contra Kant.

Kant draws a clear distinction between (on the one hand) the 'land of truth' defined by the transcendental principles of the understanding, which employ schematized categories and possess rational necessity on account of the cognitions which they enable; and (on the other hand) the broader sphere opened up by the faculty of reason, which employs unschematized categories in its attempt to determine noumenal objects and whose Ideas remain merely problematic, or serve only for regulative employment (or for pure practical reason). The shortfall of Kant's transcendentally grounded cognition in relation to the PSR is expressed in the concept of the unconditioned. The various transcendental necessities that condition human cognition - space and time, the 'I think', the principles of the understanding - are empirically unconditioned but not self-grounding, and hence not absolutely necessary or necessary in themselves. We have no knowledge of their individual or collective grounds: we cannot understand why our intuition should be spatial and temporal, and we cannot grasp the ground of the I or the common root of sensibility and understanding, any more 
than we can grasp the ground of the manifold of sensation; indeed we cannot even form a determinate concept of the totality which our cognitive powers jointly form. The transcendental frame of human cognition holds itself together from the inside but as far as we are concerned - from our confined perspective - must be regarded as floating unanchored in the unconditioned, which we can think, but not know, as containing the sufficient reason for our mode of cognition.

Now from this point there are two directions in which one may proceed in order to get understanding and reason to coincide. Either the limits of the transcendental can be pushed back, or the scope of reason can be contracted. The German Idealists do the former, Schopenhauer does the latter. Both allow it to be said that the PSR is the highest principle of transcendental philosophy and vice versa, but the direction taken is crucial for where we end up: if we enlarge the sphere of the transcendental, then we are affirm that reason plays as much of a transcendental role as the understanding, and that the unconditioned can be determined conceptually; while if we contract reason, we reduce the unconditioned to the principles of the understanding, and rule out any other conception of a thinkable object or cognitive power. Schopenhauer's conviction that reason needs to be contracted derives from his belief that, if Kant's position is left as it is, it will inevitably (under pressure from skeptics such as Schulze) end up being converted into German Idealism. ${ }^{12}$ This is the lesson Schopenhauer had learned from his years of exposure to Schelling and Fichte.

3. Undermining German Idealism. Schopenhauer is correct in his perception of the German Idealists as implicitly endorsing and in effect reactivating the PSR. Within each of their systems, the PSR emerges in new dress, and does essential work. Fichte (in the later Jena Wissenschaftslehre) affirms it in the form of what he calls the 'principle of reciprocal determination' (Wechselbestimmung). Hegel validates it in his Doctrine of Essence in The Science of Logic. These are however only its explicit manifestations. At a more fundamental level, the German Idealists' commitment to the PSR is expressed in their demand for full systematicity, which they hold to be a condition of Wissenschaft and invoke as a reason for judging Kant's Critical philosophy inadequate: if it were not for the pressure exerted by the PSR, there would be nothing objectionable per se in Kant's dualism and the German Idealists would have no compelling ground for going beyond Kant in his own name by expanding the transcendental to take in reason and the unconditioned demands which are explicit in Schelling's earliest publication. ${ }^{13}$

Schopenhauer's strategy is therefore well conceived: if the PSR could not amount to more than the four sub-principles, then all of German Idealism's inflationary metaphysics fall to the ground, clearing the way for the path that Schopenhauer wants to build from Kant to an antioptimistic axiological vision, or, in the more positive terms characteristic of his earliest reflections, for the vindication of his 'better consciousness'. 
II.

One question which now arises, of a systematic rather than historical nature, concerns the effectiveness of Fourfold Root as a criticism of German Idealism. The immediate difficulty is of course that Schopenhauer's deflation of the PSR does not, as noted, rest on any kind of proof: its argument appears to consist simply in Schopenhauer's reiteration of Kantian doctrines concerning the a priori conditions of cognition, and this suffices only to separate the transcendental from the merely rational, not to reduce reason to the transcendental.

There is an obvious danger that the basic assumptions of both parties are so flatly contradictory that no critical exchange between them is possible, but what mitigates the difficulty, and gains for Schopenhauer a momentary advantage, is an issue which neither can shirk and on which Schopenhauer puts a great deal of weight, namely the requirement that metaphysical discourse be demonstrably meaningful. Schopenhauer's vocal complaints of the unintelligibility and emptiness of German Idealist philosophy suggest at times a bare refusal on his part to attempt to understand Fichte, Schelling and Hegel, but they also contain a serious philosophical point, one that Fichte and Hegel (if not Schelling) themselves acknowledge: if philosophy is to complete its task, then it needs to explain and justify, in the eyes of ordinary understanding, its ascent to a putatively higher (transcendental for Fichte, and speculative for Hegel) standpoint and to demonstrate that its concepts are not cognitively defective in the manner of, according to the first Critique, transcendent metaphysics.

The philosophical discourse of German Idealism is built up by way of metaphilosophical reflection on Kant and other earlier philosophy, which is why so much of the systematic reconstruction of German Idealism consists characteristically in attempting to trace its basic notions back to Kant. Even if we find convincing the German Idealists' attempts to justify their speculative discourses, Schopenhauer is right to point out the greater proximity of his own metaphysical discourse to ordinary thought, and to claim that it gives his own system all of the advantages of immanence over the dubious quasi-transcendence of the German Idealists. Even transcendental idealism in Schopenhauer's hands becomes, like Berkeley's idealism, less a solution to technical problems concerning the justification of knowledge claims and more of a would-be immediately ascertainable truth of ordinary consciousness. And as Schopenhauer argues repeatedly and in detail, ordinary human life abounds with cues and intimations, provocations and invitations, to rise to the standpoint of 'better consciousness'. Aside from Fichte's intermittent appeals to Kant's moral Fact of Reason - the authenticity of which as a component of ordinary consciousness is in any case disputed - this groundedness in how-things-are-actually-given has no real parallel in Fichte, 
Schelling and Hegel, who segregate philosophical reflection sharply from the natural attitude, which they treat as an explanandum, and not as a resource for philosophical explanantia.

However, it is precisely here, in connection with the question of the conditions of meaning of philosophical discourse, that we also encounter a deep and all-too familiar problem in Schopenhauer's philosophy, which bears on the basic structure of his system and, very plausibly, cannot be resolved by any fine-tuning of his claims about representation and will.

If Schopenhauer is right that the limits of thought are determined by the content of intuitive representations and our power of abstraction from these,${ }^{14}$ then thought cannot determine any object, and so cannot have any content, that does not contain reference to, and is not derivable in some way from, the intuitive representations of the subject. ${ }^{15}$ The implications of such concept empiricism, as just stated, are not completely clear, since everything depends on what counts as abstraction or derivation. And here the claims of Fourfold Root are decisive: no legitimate abstraction or derivation can go further than spelling out the presence of the four forms of the PSR in the objects and relations given in intuitive representation.

This restrictive condition on conceptual meaning allows Schopenhauer to immediately close down speculation concerning an 'absolute ground of reason' or a 'ground in general', but it creates a problem with regard to Schopenhauer's own aim to describe in concepts the excess of reality over representation, which now seems by his own lights not merely unwarranted but strictly nonsensical. The problem shows up at many points - most obviously and prominently, in $W W R$, in the idea that will is the ground of the world as representation, but also to a lesser extent in the theory of Ideas, which involves application of the category of quantity ('degrees' of objectification) and individuation beyond the sphere of representation (the difference of one Idea from another). ${ }^{16}$

In Fourfold Root, this problem does not show up as such, because there Schopenhauer does not say anything about what lies outside the world as representation. There is however another problem in the early text suggesting a breach of immanence. This lies in the ambiguity surrounding the either-unitary-or-aggregative character of the PSR, and the assumed-but-ungrounded harmony of its various sub-forms. Is the PSR one principle, differentiated into four forms, or is it a mere conjunction of discrete principles? Schopenhauer equivocates throughout - in fact the equivocation is expressed in the title of the work - but the question is crucial, and both options create difficulties, which explains why his answer should appear so undecided.

If the former - if the PSR is a genuine unity - then there is an essence of reason, which may be expressed necessarily in each of the four sub-forms but cannot be regarded as expressed fully in any of them individually. The concept of this essence could not have arisen through mere abstraction. The question also then arises - since it is hard to see why, if no individual sub-form exhausts reason, the conjunction of the four sub-forms should do so - what prevents us from 
constructing new sub-forms of the principle: for example and in particular, a principle governing the relation of the realm of representation as a whole to its ground.

If on the other hand the PSR is a mere aggregate - if there are four principles each with their own root, and 'reason' is a disjunct which means 'one or other of the four underived basic structuring principles' - then Schopenhauer is missing an explanation for why the sub-forms of the PSR do not part company with one another. What ensures the coordination of the various domains of objects attached to each sub-principle? What, for instance, ensures that the portions of matter-filled space and time that we individuate in accordance with the third sub-form are related coherently to the causal sequences determined by the first sub-form? What stops this portion of matter-in-space, this table, being directly plugged in causally to some other portion on the other side of the planet? Again, what ensures that the order of truth and inference tracks the causal order? Why should the order of my judgements, the beliefs that I have reason to form, follow the order of the empirical content of my experience?

These are not ('mere') skeptical problems, which might be dismissed as expressing only hyperbolical doubt: they are properly transcendental questions, closely related to those that define the tasks of Kant's Transcendental Deduction (why should appearances not 'be so constituted that the understanding [does] not find them in accord with the conditions of its unity'? ${ }^{17}$ ) and Second Analogy ('How am I to understand the fact that, because something is, something else is ?'18).

Kant has the basis for an answer to such questions - if the various principles of the understanding did not harmonize with one another, and with the forms of intuition, then no unity of consciousness would be possible - which is not available to Schopenhauer, given his abnegation of transcendental proof. And if Schopenhauer does not recognize the questions as meriting attention, then that is because (so it may be argued) he has surreptitiously assumed a fifth, superordinate form of the PSR, which keeps the four subordinate principles aligned, operating so to speak behind the back of representation, that is, playing the role of Kant's transcendental unity of apperception.

If correct, this immediately reverses the balance of argument between Schopenhauer and the German Idealists. Their success in securing the meaningfulness of speculative philosophical discourse - by appeal to 'intellectual intuition', the method of Konstruktion, the experience of pure thinking, and so on - may be doubtful, but their efforts do not result in inconsistency. Schopenhauer's claims, by contrast, seem to generate exactly that: a strict contradiction between his restrictions on conceptuality on the one hand, and his metaphysics of the world as will and need for a unitary ground of the world as representation on the other.

III. 
The problem of how to give systematic form to the limitations of systematicity is of Kantian provenance and Schopenhauer's aggravated version of it has a long and well-explored after-history. As commentators have suggested, its effects can be felt in the skepticism of Nietzsche's early 'On Truth and Lies' essay, in Hartmann's suggestion that Schopenhauer's system needs to be fused with Hegel's in order to supply the ideational components missing from his metaphysics of will, and in the Tractatus' distinction of what can be said from what can only be shown.

That Schopenhauer should put himself in the situation of advocating such a metaphilosophically convoluted form of post-Kantianism deserves as much explanation as can be provided. I have already suggested what provides his motive - his wish to force philosophical reflection to a conclusion which is alien to its inherently rationalistic nature. The question which needs to be addressed is how and why - by what logical path - this essentially axiological conviction gets translated itself into the doctrines expounded in Fourfold Root and WWR.

We find a great deal in Schopenhauer's immediate philosophical environment that can be taken to point in the direction he takes. Haym puts it well when he describes the history of the genesis of Schopenhauer's philosophy as 'the solution to the riddle of how so many incongruent features can nonetheless give the impression of a single, attractive and distinctive physiognomy'. ${ }^{19}$ There is much to be said on this topic but I will confine myself to three points. ${ }^{20}$

1. Kant. Schopenhauer thinks of himself as retrieving Kant's true insight and stripping away the retrograde features with which Kant had unfortunately bound it up, due to his immersion in Wolffian philosophical culture. When we see how much of Kant's system Schopenhauer wants to jettison, we may wonder what exactly his professed Kantian allegiance amounts to, but Schopenhauer is surely right to emphasize his incorporation of the Aesthetic's doctrine of transcendental idealism and Kant's theory of intelligible character as testifying to his genuine continuity with Kant. Less obvious but also of huge importance, I suggest, is his appropriation of what might be called Kant's affirmatively aporetic metaphilosophical stance, by which I mean the following.

There is, as noted, a close relation between the problem of bounding cognition that faces Schopenhauer, and the familiar high-level problem encountered by transcendental idealism. In effect the error that Schopenhauer appears to make at the level of meaning is the one that Kant is standardly charged with making at the level of epistemology: allegedly, Schopenhauer shouldn't, but does, think that a ground of the world as representation can be conceived, and Kant shouldn't, but does, think that we can know that things in themselves are the grounds of appearances. And the closely allied charge levelled by Hegel, that Kant must overstep the limits of knowledge in order to draw them, appears to have straightforward application to Schopenhauer too. 
This familiar line of objection to Kant's transcendental idealism has been restated very clearly, and endorsed, by Adrian Moore in his recent history of metaphysics. ${ }^{21}$ Moore describes the task of metaphysics as that of making sense of things in the most general terms, which involves making sense of its own making sense of things. And the problem with transcendental idealism, according to Moore, is that it fails to do this, for it is embroiled, if not in contradiction then at least in self-stultification: 'At a more general level, we cannot represent limits to what we can represent. For if we cannot represent anything beyond those limits, then we cannot represent our not being able to represent anything beyond those limits. ${ }^{22}$ Therefore, Moore concludes, transcendental idealism is incoherent.

This is not the place for detailed discussion, ${ }^{23}$ but my view is that, while Moore is quite right to highlight the sense in which transcendental idealism fails to account for itself, it does not result in contradiction or self-stultification, for the reason that the Kantian transcendental idealist disavows any intention to make sense of sense-making in the way that Moore requires - that is, in a way that is symmetrical or continuous with our making sense of objects - and also justifies this disavowal: it is a positive claim of transcendental idealism that we have no insight into the real ground of our sense-making capacities. Kant's transcendental epistemology offers itself as a means for avoiding the skepticism that might seem to follow from this admission of our cognitive limitation: it shows that and how we give justified application to, and claim necessity for, principles whose ultimate real grounds are indiscernible to us. Transcendental idealism, rather than stultifying itself, registers the actual stultification of the task of human cognition, with respect to the ultimate ends of theoretical reason, in the account that it gives of our-situation-in-relation-to-reality.

My suggestion is that the affirmatively aporetic feature of Kant's system is consciously carried over into Schopenhauer, who raises it to a higher power by extending to our conceptual capacities the bare contingency and surd quality exhibited on Kant's account by space and time; hence the denial in Fourfold Root that there can be a derivation of the PSR or any account of its source.

2. Maimon. Salomon Maimon - who is referenced in the first edition of Fourfold Root (FR, 27 [22]) - is of particular interest in the narrative of Schopenhauer's development in so far as he was the key progenitor of the systems of German Idealism, ultimately more important than Reinhold, and also, non-coincidentally, the only important early post-Kantian to lay stress on the relevance of the PSR in the critical estimate of Kant's philosophy. We find rehearsed in Maimon a line of thought that Schopenhauer could have taken to further support his conviction (as I have attributed it to him) that aporeticity is unavoidable and which also shows him, indirectly, a way to depart from the path which leads to German Idealism. 
Stated very briefly, and in the sketchiest terms, Maimon's contribution to the post-Kantian development consists in his claim to demonstrate that Kant fails to satisfy the demands of the PSR, which he cannot escape, for the decisive reason that he fails in his endeavour to provide an epistemologically satisfactory alternative: even when the conditions on knowledge are scaled down and made immanent to subjectivity in the way transcendental idealism proposes, our knowledge claims are, Maimon argues, insufficiently grounded. This failure, according to Maimon, stems from Kant's thesis of the aboriginal independence and heterogeneity of sensibility and understanding, which makes it impossible to give grounds for thinking that what we take to be the objective application of the categories is really any such thing, i.e., that the categories of substance and cause are genuinely constitutive of any object given in experience. In other words, Kant's Analytic leaves Humean skepticism unscathed, and this is ultimately because Kant denies all intrinsic conceptual character to the data of sense.

The moral drawn by Maimon is that, since the demands of the PSR cannot be met through Kant's transcendental logic, and since failure to meet them entails radical skepticism, the PSR needs to be reinstated as a supreme principle of philosophical reflection (in the novel form of what he calls the Satz der Bestimmtbarkeit, the Principle of Determinability). Maimon's further argument is that this principle requires us to revert to Leibniz's intellectualist conception of the data of sensibility and forms of intuition, and moreover, to treat finite minds as moments of an infinite intellect.

If Maimon is right that Kant's transcendental deduction of the categories fails because of his dualism of sensibility and understanding, then German Idealism, in so far as it seeks to overcome this dualism, is well motivated. However, the other way in which one could respond to Maimon's discovery - instead of following him in his attempting to upgrade the transcendental in the direction of Leibniz, ${ }^{24}$ a move which demands epistemic transcendence (the positing of the infinite intellect) - is to downgrade the PSR in the direction of Hume: that is, to declare that there can be nothing more to reason than the forms of representation that we, as a matter of fact, find ourselves with, and that there can be nothing more to objectivity than the de facto internal structure of representation. Such a move obviates the need for transcendental logic, by disposing of the idea that there could be anything constitutive of objects beyond the reach of proof. ${ }^{25}$ This is what Schopenhauer does in Fourfold Root. In this way his strategy can be seen to emerge from the very same source as German Idealism, even as it heads in the opposite direction.

3. Schelling. I have described Schopenhauer as presenting a critique of German Idealism from a putatively Kantian standpoint and as offering a systematic alternative, but he was not the first to do so. Fries had done the same in his New Critique of Reason (1807), as Schopenhauer knew ${ }^{26}$ and so too, in a quite different way and with much greater importance for Schopenhauer, 
had Schelling in his writings following his exposition of the Identity Philosophy (1801-04). Schopenhauer's Berlin manuscripts contain notes on Schelling's Philosophie und Religion (1804) and later writings including the Freiheitsschrift (1809), ${ }^{27}$ in which Schelling does exactly what Schopenhauer will later do in WWR: he draws a limit to the space of reasons and characterizes what lies outside it as Wille. He does so moreover in the name of acknowledging the reality of evil: the Freiheitsschrift argues that human freedom has reality only if evil has reality, and that evil is possible only if the absolute has a certain structure, whereby 'blind longing' precedes the genesis of reason and functions thereafter as its continuing, indispensable source. ${ }^{28}$

This is but one of the numerous points of contact with Schelling - others include the double aspect structure of the system of philosophy, the elevation of art to parity with philosophy, and the general notion that the task of philosophy is born from our 'egress from the absolute'. ${ }^{29}$ What matters presently, however, is not Schopenhauer's reproduction of Schelling's teachings but his creatively destructive relation to Schelling's later philosophy, in which the PSR has been demoted but is never abandoned. Schelling's high wire act, seeking to balance the claims of reason with the insight into a volitional reality which transcends it, continues into the $1840 \mathrm{~s}$, and in Schopenhauerian perspective seems a forlorn attempt to reconcile the irreconcilable. Schopenhauer might, therefore, have described WWR (Hartmann for one suggests) as a radical revision to Schelling's later metaphysics, doing with Schelling in Book 2 of WWRI what he describes himself as doing in Book 1 with Kant, and Fourfold Root as the only tenable account of the PSR once the inadequacy of reason to the traditional task of metaphysics has been grasped.

\section{IV.}

Having argued that Fourfold Root fails to supply Schopenhauer with the metaphilosophy that he needs in $W W R$, I now want to consider the possibilities for his defence. What other metaphilosophy might serve Schopenhauer's purposes in $W W R$ ?

We may begin with a brief comparison of Schopenhauer's metaphysics of will with Kant's theory of reason. In the Transcendental Dialectic, Kant explains away reason's Ideas of unconditioned objects in terms of, on the one hand, the conditions and objects of the understanding, and on the other, the specific need of reason, which Kant suggests can be identified with the purely formal function of achieving absolute unity and totality. Such transcendental reflection resolves the Ideas of reason back into the elements from which they were formed, whereby they lose their power to project objects (this is so for philosophical reason if not for natural reason). Once all this has been done, however, Kant has the Ideas return in the contexts of reason's regulative employment and the postulates of pure practical reason, which require that their object-projecting power be 
restored to them. Kant's solution to the problem which he at this point faces - how can we legitimately attempt to think the supersensible determinately, for example, think of God as endowed with infinite power and wisdom, and do so without reanimating a transcendental illusion? - is to say that judgement here proceeds by analogy, that is, by treating supersensible objects as analogical with sensible objects. ${ }^{30}$

Why cannot Schopenhauer say the same, that is, describe his use of concepts in order to think the relation of the world-as-will to the world-as-representation as a case of analogical thinking? $?^{31}$ The reason is simply that analogical cognition - moving predicates across the sensible/supersensible divide - can get going only once the two domains have already been established. If I am to think A on the analogy with B, then A must already be posited, hence must be thinkable. Now Kant is entitled to presuppose the supersensible domain, because he has affirmed that thought per se has an a priori foundation which does not tie conceptual significance exclusively to sensible representation, and because he has also shown that the sensible domain fails to account sufficiently for itself. In other words, the unconditioned is securely in place for Kant before we undertake to determine it by an analogical use of concepts. Schopenhauer by contrast has scotched the very possibility of another 'domain' capable of bearing analogical relation to the worldas-representation: if we try to talk of a 'determinable domain analogous to the domain governed by the PSR', then we are either, Schopenhauer must say, talking about the world as representation once again, a mere duplicate thereof, or we are saying nothing at all.

What makes Schopenhauer think otherwise, in $W W R$, is that he believes himself to have discovered in the experience of willing a rift in the fabric of the world as representation, an item within experience which testifies to the existence of an extra-representational domain or other 'aspect' of the domain of representation. Now the problem concerns the nature of this alleged fact of consciousness. It cannot (by Schopenhauer's rules) be inherently conceptualized in the same manner as perception, for if it were then it would represent an object, in accordance with the PSR. ${ }^{32}$ So its conceptual articulation - our thinking of this putative fact in a way that permits our extraction of meaning from it - must, it seems, involve our bringing concepts to it. But what concepts? Certainly we can think that this experience - of volition or hedonic affect - is something which has nothing in common with representations structured by the PSR, but what we cannot do, with the conceptual resources Schopenhauer allows us, is move from this wholly negative characterization to any positive determination (we can think, as it were, 'this doesn't fit', but cannot say what 'this' is, nor what about it makes it incongruent with representation).

It seems that only one alternative remains. If we cannot get the experiential datum to speak by bringing concepts to it, then it must speak for itself. That is, in order to extract anything positive from volitional experience Schopenhauer must affirm that the experience contains, or makes 
provision for, its own conceptualization - it tells us what its nature is. The suggestion is of course not supported by the letter of Schopenhauer's texts, but it has (just) enough coherence to do the work needed.

One worry here is that, if Schopenhauer posits an intuition which is independent of the PSR yet for all that not blind, then he seems to have allowed himself, in effect, the intellectual intuition that he derides in Fichte and Schelling. ${ }^{33}$ Putting the point in the terms of Fourfold Root, it may seem that he has allowed a further form of reason additional to those that structure the world as representation, and thus has done exactly what he objects to in German Idealism. Some commentators have indeed suggested that Schopenhauer here shows himself to be a Fichtean or Schellingian. Arguably this is too quick. While it is true that Schopenhauer has expanded his epistemology and come close to admitting a 'higher faculty of knowledge', he has certainly not licensed the project of speculative philosophy. What Schopenhauer needs to maintain, regarding the experience of will, is only that (i) it manifests its own incongruity with the world as representation, displaying itself as independent from and foreign to the PSR, as being of a nature that repugns our $a$ priori concepts; and (ii) it presents itself as more primitive than representation. These relational properties must be held to flow directly from the non-relational essence of will as it is disclosed to us, the intrinsic self-intimating quality of the experience of volition. But Schopenhauer is not obliged to agree that, having registered the meaning of the experience of volition, there is anything more that we can do with it, epistemologically. On the contrary, his position can be that, precisely because what is revealed is without thinkable internal structure, it does not put us in possession of a conceptual form that could be redeployed in metaphysical reflection. Unlike the intellectual intuition of Fichte and Schelling, therefore, it does not supply a metaphysical template, a clue to the hidden reason of things. It marks an end point for philosophical reflection, not a launching pad. And yet it qualifies as insight.

A question nonetheless remains. Even granting that volitional experience can contain this metaphysical information, which we grasp in the mode of feeling, still we need to be able to take it up in reflection and extract from it the philosophical concept of will as a domain or world-aspect, distinct from that of representation. So what in our conceptual repertoire enables us to do this? It seems that we are back with the question we started with.

What Schopenhauer must say, under such intense pressure and for want of any alternative, is that the use made of concepts in thinking the relation of the world-as-will to the world-asrepresentation as a relation of grounding, is, as several commentators have proposed, a species of metaphorical usage. ${ }^{34}$ In a way this is to go back to the analogical predication idea. But the new formula avoids the earlier difficulties. If the case is one of metaphor, then we do not commit ourselves to specifying the likeness that underpins it, but only to exhibiting the route by which we 
arrive at it - this is the only sense in which we are bound to justify discursively the metaphorical transference of intra-representational grounding to extra-representational relations. This surrender of discursive responsibility is what makes it a case of metaphor, not one of analogy. Nonetheless, we can affirm its rightness, metaphorical aptness, in light of the experience of willing.

If this means, and perhaps it does, that when we think of the world-as-will as ground of the world-as-representation, we are not strictly thinking that anything is the case, then Schopenhauer must accept the implication and agree that to think the world as will is not, formally speaking, to judge any state of affairs. But this does not leave him empty-handed. The species of thought (or 'quasi'-thought) that the world-as-will admits of, Schopenhauer may say, is instead expressive. Leaning on the etymology of expression, the 'object' or 'content' of thought - here, Wille - may be regarded as pressing itself out into thought, and so perhaps as being also, in some admittedly strange sense, the subject that does the thinking. What matters at any rate is that the world's 'being in essence will' is a thought that comes to $u s$, rather than a conclusion that we come to through the spontaneity of our thinking. This passive, receptive mode of philosophical cognition would therefore contrast, in an appropriate way, with the way in which we come to know the apodictic truths of the PSR: truths concerning the world-as-will would semi-literally force themselves upon us - they 'strike' us, as one says ${ }^{35}$ - rather than being simply and banally self-evident in the manner of the principle of causality.

This would mean that Schopenhauer's system is not really, appearances to the contrary, a rival standing on the same plane as the systems of the German Idealists. When Schopenhauer declares that the world in itself is unindividuated Wille, this thesis is not of the same order as Hegel's claim that it is the movement of the Concept or Fichte's claim that it is the activity of the pure I. Schopenhauer's disagreement with Fichte and Hegel would then consist, not in his offering a competing conceptual determination of the essence of reality, but in a denial that any such characterization is possible.

To be sure, it must seem initially that Schopenhauer loses something in his argument with German Idealism by relinquishing claims for the literal truth of his metaphysics of will, but if so, he gains on the other side by relocating his disagreement at an even more fundamental level. And again, if the result is to make Schopenhauer's metaphysics akin to an aesthetic construction, this is not necessarily to their disadvantage: if their truth is a matter of their aesthetic force, and if aesthetic force is understood in the (semi-realist) way described above, and if this is the only kind of truth (correctness, warrant) available and appropriate to talk of the ground of the world of representation, and if no other theory has comparable aesthetic force, then Schopenhauer's aesthetically validated metaphysics has a full complement of epistemic virtues (and is not aesthetic in any sense which contrasts with the serious business of thinking). It lacks, of course, the pure rational foundation 
which the German Idealists regard as the sole virtue worth having, but it is Schopenhauer's claim, which his system in a certain sense explains, that that demand is in error. If Schopenhauer is right, there is a good sense in which we do not know what we are doing when we engage in metaphysical reflection - this is a direct implication of Fourfold Root, which tells us that the transcendent perspective required to conceive reason as grasping reality in itself is an absurdity. What sustains our commitment to the warrantedness of his metaphysics, Schopenhauer may insist, is the absence of any alternative: face to face with the world as we find it, there are certain things that, we find, we have to think.

It must be asked of course to what extent this extreme construal of Schopenhauer's metaphilosophy matches his own understanding. While we do not find anywhere an outright affirmation of this view as just formulated, it certainly coheres with passages, particularly in the early Nachla $\beta$, in which Schopenhauer classifies philosophy alongside Kunst in opposition to Wissenschaft, and describes the philosopher as possessing genius and engaged in painting in concepts, deploying reflection in order to refract the content of intuition but not in the service of explanation. Philosophy is, or should be, Schopenhauer says, 'a reflected image [reflektirtes Abbild] in permanent concepts' of the inner nature of the world (WWR1, 410 [453]). Also relevant are Schopenhauer's statement in the Appendix of WWRI that Kant sought a 'science from [or of: aus] concepts', whereas his own philosophy is a 'science in concepts' (WWRl, 481 [537]), and the continuity of art with philosophy implied by his description of it, in the conclusion of Book 3 , as providing clarification, Verdeutlichung, of the visibility of the world (WWR1, 295 [315]). ${ }^{36}$

\section{V.}

I have claimed that the minimalist metaphilosophy of Fourfold Root, even if it were adequate in its own terms, could not serve the purposes of WWR. Even if Fourfold Root is justified in supposing that the PSR hangs in the void, neither grounded nor self-grounding, an ultimate bare factum, more is needed metaphilosophically when Schopenhauer steps out of its sphere, specifically, an account of the source of the significance of the claims which compose his metaphysics of will. Whether or not the aesthetic construal is satisfactory, it is highly unlikely that a straightforward logical solution to the difficulties indicated above can be found: even if Schopenhauer's metaphysics of will could be formally reconciled with his thesis of the limitation of thought, so much twisting and turning will be required that it will be doubtful that we remain in the spirit of Schopenhauer's thought. Here is an alternative perspective on the problem, which supplements the aesthetic construal.

That Schopenhauer was fully aware of the peculiarity of his position seems not open to doubt. His allusion to a 'miracle' at the core of his system (WWR1, 126 [121], and FR, 136 [143]) 
acknowledges that it is not a theory of the standard type familiar from German Idealism, and the inconsistencies it exhibits are not buried but at the surface: they were rapidly identified and spelled out comprehensively in the earliest nineteenth-century commentaries on Schopenhauer. ${ }^{37}$

My suggestion is that Schopenhauer is willing to tolerate formal inconsistences in his system because he believes them to be justified in an oblique fashion by what it brings to light. Schopenhauer's standpoint may be reconstructed as follows. Systematicity is inescapable for philosophical reflection in so far as it expresses an aspiration to totality and all-comprehension. However, it cannot properly be determined in advance what direction our reflection will take and what different forms of consciousness will weigh with us, and nor, therefore, can it be determined what will result from the combination of our findings and what shape the system will finally have. In order for philosophical reflection to be genuinely open and unbefangen, a wholly indeterminate conception of the system of philosophy as simply whatever we find ourselves once all things have been run through is required - contra Kant, Fichte, Schelling, and Hegel, who all maintain that the very concept of a system is given in advance and properly constrains the path of philosophical reflection. If it seems otherwise - if it seems to us that achieving systematicity is necessarily equivalent to making the All transparent to Reason and explaining Reality all the way down - then that is because we are victims of the prejudice (rooted in the will to life) that Fourfold Root attacked, of supposing the PSR to be not a mere form of cognition but the very substance of the Real. If the failure of Schopenhauer's system to 'add up' is attributable to its object, viz., reality-andour-situation-within-it, then its inconsistencies can be condoned, and to deploy them as criticisms is merely to wish that things were not as they are and that our situation were not as it is. In sum, if we want to see reality rendered comprehensively (and philosophy can have no other mission), then we commit ourselves to accepting the final product of our endeavour, whatever its logical character. The systematic endeavour is not abortive, since Schopenhauer's system does not return us to where we started from, rather it takes us to a point where the questions with which we were originally confronted have been dissolved away.

To return to the aesthetic analogy: though we may begin philosophy with the expectation that the system of philosophy will have the form of a piece of classical architecture, the lesson of reflection, if it remains faithful to actual experience, is that the true system has a much stranger shape and incorporates all of the juxtapositions and dissonances of artistic modernism.

To thus urge comparison with appropriate works of art is not to say that Schopenhauer ought really to have employed an artistic medium for articulating his vision, or that his worth lies merely in his having paved the way for The Man Without Qualities. It is quite true, as the spectacular history of his influence on artists and writers attests, that internalization of Schopenhauer's thought conduces naturally to non-philosophical forms of expression, but the essential point, not to be lost 
sight of, is that his system validates the transition to these other modes of sense-making: in providing this bridge, the system does not discharge itself or make itself redundant, for we do not and could not find Schopenhauer's system re-expressed in any work of art. It retains its position, as an arrow pointing the way. Systematic philosophy and fine art thus form a unity, not in the way described in Book 3 of WWRI but at the level of Schopenhauer's metaphilosophy.

\section{Bibliography}

Cartwright, David, Schopenhauer: A Biography, Cambridge: Cambridge University Press, 2010.

Euler, Leonhard, Letters to a German Princess (1768), extracts in Eric Watkins (ed.), Kant's

Critique of Pure Reason: Background Source Materials, trans. Eric Watkins, Cambridge:

Cambridge University Press, 2009.

Fischer, Kuno, Geschichte der neuern Philosophie, Vol. 9, Schopenhauers Leben, Werke und Lehre, Heidelberg: Winter, 1897.

Franks, Paul, All or Nothing: Systematicity, Transcendental Arguments, and Skepticism in German Idealism, Cambridge, MA: Harvard University Press, 2005.

Gardner, Sebastian, 'Schopenhauer's Contraction of Reason: Clarifying Kant and Undoing German Idealism', The Kantian Review, 17, 2012, 375-401.

Gardner, Sebastian, 'Transcendental Idealism at the Limit: On A. W. Moore's Criticism of Kant', Philosophical Topics, 43, Nos. 1 \& 2, Spring/Fall 2015, 1-23.

Haym, Rudolf, Arthur Schopenhauer, Berlin: Reimer, 1864.

Herder, J. G., Fragments on German Literature (1767-68), in Philosophical Writings, ed. Michael Forster, Cambridge: Cambridge University Press, 2002, pp. 33-64.

Hübscher, Arthur, The Philosophy of Schopenhauer in its Intellectual Context: Thinker Against the Tide, Lewiston, NY: Mellon, 1989.

Kant, Immanuel, 'Attempt to Introduce the Concept of Negative Magnitudes into Philosophy' (1763), in Theoretical Philosophy, 1755-1770, trans. and ed. David Walford and Ralf Meerbote (Cambridge: Cambridge University Press, 1992.

Kant, Immanuel, Critique of Pure Reason, trans. and ed. Paul Guyer and Allen Wood, Cambridge: Cambridge University Press, 1998.

Kant, Immanuel, What Real Progress has Metaphysics Made in Germany Since the Time of Leibniz and Wolff? (1793), in Theoretical Writings After 1781, ed. Henry Allison and Peter Heath, trans. Gary Hatfield, Michael Friedman, Henry Allison and Peter Heath, Cambridge: Cambridge University Press, 2002, pp. 337-424.

Liebmann, Otto, Kant und die Epigonen. Eine kritische Abhandlung, Stuttgart: Schober, 1865. 
Maimon, Salomon, Versuch einer neuen Logik oder Theorie des Denkens, nebst angehängten Briefen des Philateles an Aenesidemus, Berlin: Felisch, 1794.

Moore, A. W., Points of View, Oxford: Oxford University Press, 1997.

Moore, A. W., The Evolution of Modern Metaphysics: Making Sense of Things, Cambridge:

Cambridge University Press, 2012.

Neeley, G. Stephen, 'Schopenhauer and the Limits of Language', Idealistic Studies, 27, 1997, 4767.

Neeley, G. Stephen, 'The Consistency of Schopenhauer's Metaphysics', in Bart Vandenabeele (ed.), A Companion to Schopenhauer, Oxford: Blackwell, 2012, 105-119.

Schelling, F. W. J., On the Possibility of a Form of All Philosophy (1794), in The Unconditional in Human Knowledge: Four Early Essays 1794-1796, trans. and ed. Fritz Marti, Lewisburg: Bucknell University Press, 1980.

Schelling, F. W. J., Of the I as Principle of Philosophy (1795), in The Unconditional in Human Knowledge: Four Early Essays 1794-1796, trans. and ed. Fritz Marti, Lewisburg: Bucknell University Press, 1980, pp. 38-58.

Schelling, F. W. J., Philosophical Letters on Dogmatism and Criticism (1795), in The

Unconditional in Human Knowledge: Four Early Essays 1794-1796, trans. and ed. Fritz Marti (Lewisburg: Bucknell University Press, 1980), pp. 63-149.

Schelling, F. W. J., Philosophical Investigations into the Essence of Human Freedom and Matters Connected Therewith (1809), trans. Jeff Love and Johannes Schmidt, Albany, NY: State University of New York Press, 2006, pp. 156-218.

Schopenhauer, Arthur, On the Fourfold Root of the Principle of Sufficient Reason and Other Writings [FR; ER for the first edition for the work], trans. and ed. David Cartwright, Edward Erdmann and Christopher Janaway, Cambridge: Cambridge University Press, 2012.

Schopenhauer, Arthur, The World as Will and Representation, Vol. 1 [WWRl], trans. and ed. Judith Norman, Alistair Welchman and Christopher Janaway, Cambridge: Cambridge University Press, 2010.

Schopenhauer, Arthur, The World as Will and Representation, Vol. 2 [WWR2], trans. E. F. J. Payne, New York: Dover, 1969.

Schopenhauer, Arthur, Vorlesung über die gesammte Philosophie d.i. Die Lehre vom Wesen der Welt und von dem menschlichen Geiste. In vier Theilen. Erster Theil: Theorie des gesammten Vorstellen, Denkens und Erkennens (1820), in Theorie des gesammten Vorstellens, Denkens und Erkennens. Aus dem handschriftlichen Nachlaß, ed. Volker Spierling, München: Piper, 1986, pp. 85-572. 
Schopenhauer, Arthur, Manuscript Remains in Four Volumes [MR], trans. E. F. J. Payne, ed. Arthur Hübscher, Oxford: Berg, 1988.

Schröder, Wilhelm, Beiträge zur Entwicklungsgeschichte der Philosophie Schopenhauers. Mit besonderer Berücksichtigung einiger wichtiger frühnachkantischer Philosophen (Maimon, Beck, G. E. Schulze, Bouterwek und Jacobi), Rostock: Bold, 1911.

Shapshay, Sandra, 'Poetic Intuition and the Bounds of Sense: Metaphor and Metonymy in Schopenhauer's Philosophy', European Journal of Philosophy, 16, no. 2, 2008, 211-229.

Ueberweg, Friedrich, History of Philosophy, Vol. 2, History of Modern Philosophy, trans. George Morris, New York: Scribner, 1909.

Vasalou, Sophie, Schopenhauer and the Aesthetic Standpoint: Philosophy as a Practice of the Sublime, Cambridge: Cambridge University Press, 2013.

Weiß, Otto, Zur Genesis der Schopenhauerschen Metaphysik, Leipzig: Thomas, 1907

White, F. C., On Schopenhauer's Fourfold Root of the Principle of Sufficient Reason, New York: Brill, 1992.

Wolff, Christian, Vernunfftige Gedancken von Gott, der Welt, und der Seele der Menschen, auch allen Dingen überhaupt, 7th edn., Frankfurt u. Leipzig, 1738.

Zeller, Eduard, Geschichte der deutschen Philosophie seit Leibniz, 2nd edn., München:

Oldenbourg, 1873.

${ }^{1}$ References to and quotations from Schopenhauer are to the following editions: On the Fourfold Root of the Principle of Sufficient Reason and Other Writings [FR; ER for the first edition for the work], trans. and ed. David Cartwright, Edward Erdmann and Christopher Janaway (Cambridge: Cambridge University Press, 2012); The World as Will and Representation, Vol. 1 [WWR1], trans. and ed. Judith Norman, Alistair Welchman and Christopher Janaway (Cambridge: Cambridge University Press, 2010); The World as Will and Representation, Vol. 2 [WWR2], trans. E. F. J. Payne (New York: Dover, 1969); and Manuscript Remains in Four Volumes [MR], trans. E. F. J. Payne, ed. Arthur Hübscher (Oxford: Berg, 1988).

${ }^{2}$ The firm implication of the Preface to WWR is that the earlier work is logically presupposed, not merely an aid to understanding.

${ }^{3}$ The review by Georg Klein, a Schellingian, in the Jenaischen Allgemeinen Literatur-Zeitung, July 1814, nos. 123-124, imputes confusion: Schopenhauer's PSR is neither the traditional principle nor properly Kantian. Schopenhauer sent Fourfold Root to Schulze, Reinhold, Schleiermacher, and August Wolff, but (to my knowledge) received no responses, aside from Schulze's unenthusiastic 
review in the Göttingischen Gelehrten Anzeigen, Stück 70, 30 April 1814, 701-703, which complains that Schopenhauer over-extends the PSR.

${ }^{4}$ Or even its antithesis: Wolff, in Vernunfftige Gedancken von Gott, der Welt, und der Seele der Menschen, auch allen Dingen überhaupt, 7th edn. (Frankfurt u. Leipzig, 1738), pp. 16-17 and 7476 ( $\$ 30$ and $\$ 143$ ), describes the PSR as sufficient for the distinction of empirical reality from dream, whereas Schopenhauer's PSR entails that empirical reality can only be a certain kind of dream.

${ }^{5}$ Another, stronger and more general implication is that being or existence in general is not something for which there could be a reason. Schopenhauer also attacks the assumption in Wolff that essence or determinacy (being thus and not otherwise) is something for which there must be a reason $(F R, 23-24[18-19])$.

${ }^{6}$ Thus in his crucial argument with Wolff in $F R, \S 10$, everything turns on Schopenhauer's invocation of Kant's restrictive account of the concept of possibility. That Schopenhauer's PSR is, at least as regards its content, reducible to (and a mere restatement of) two principles that Kant had already established, is pointed out by Friedrich Ueberweg, History of Philosophy, Vol. 2, History of Modern Philosophy, trans. George Morris (New York: Scribner, 1909), p. 260n.

${ }^{7}$ In his Letters to a German Princess (1768), Letters XIII-XIV, in Eric Watkins (ed.), Kant's Critique of Pure Reason: Background Source Materials, trans. Eric Watkins (Cambridge: Cambridge University Press, 2009), pp. 224-228.

${ }^{8}$ I use the term 'German Idealism' here, obviously, in a narrow sense.

${ }^{9}$ What follows is argued in more detail in my 'Schopenhauer's Contraction of Reason: Clarifying Kant and Undoing German Idealism', Kantian Review, 17, no. 3, 2012, 375-401.

${ }^{10}$ Schopenhauer complains of both the fogginess of Kant's conception of method and its intellectualism: see WWR1, 481-483 [537-539]. His criticism of Kant for elevating the merely abstract understanding recalls Hegel, but in its place Schopenhauer recommends immediacy, not further mediation. If Schopenhauer is right, the very method of Kantian transcendental proof is illconceived.

${ }^{11}$ See WWR1, 480-500 [536-559] on the categories. Schopenhauer allows that the Table of Judgements can be accepted, but says that the forms of judgement can all be derived from perception, the content of which they re-express in reflection: they are in fact one and all elaborations of the causality sub-form of the PSR. This coheres with Schopenhauer's criticism of Kant regarding the absurdity of supposing a causality of things in themselves. Thus, just as Kant's Transcendental Deduction is reversed by Schopenhauer - for whom we go from the understanding's 
perception to the categories - so too is Kant's Metaphysical Deduction: we go from the categories to the forms of judgement.

${ }^{12}$ See the reconstruction of Paul Franks, All or Nothing: Systematicity, Transcendental Arguments, and Skepticism in German Idealism (Cambridge, MA: Harvard University Press, 2005).

${ }^{13}$ See On the Possibility of a Form of All Philosophy (1794), in The Unconditional in Human Knowledge: Four Early Essays 1794-1796, ed. Fritz Marti (Lewisburg: Bucknell University Press, 1980), esp. pp. 49-51, and (in the same volume) Of the I as Principle of Philosophy (1795), p. 120: Schelling asserts the autonomy of the PSR, its superordinate position in relation to Kant's principles of knowledge, and Kant's reliance on it.

${ }^{14}$ A position not short of antecedents, one of the most interesting being Herder: see the semantic skepticism of Fragments on German Literature (1767-68), in Philosophical Writings, ed. Michael Forster (Cambridge: Cambridge University Press, 2002), pp. 33-64.

${ }^{15}$ See, e.g., FR, 93-94 [97-99]; WWR1, 62-65 [47-50]; MR, Vol. 2, 298-299, 468 and 471.

16 The theory of Ideas either presupposes the independence of the form 'subject-object' from the form determined by the PSR, or it introduces an entirely new sense of 'objectification' which Schopenhauer leaves unexplained. The whole issue comes to a head in the 'Epiphilosophy' conclusion of WWR2, 640-643.

${ }^{17}$ Critique of Pure Reason, trans. and ed. Paul Guyer and Allen Wood (Cambridge: Cambridge University Press, 1998), A90/B123.

${ }^{18}$ As Kant first posed it in Attempt to Introduce the Concept of Negative Magnitudes into Philosophy (1763), in Theoretical Philosophy, 1755-1770, trans. David Walford (Cambridge: Cambridge University Press, 1992) p. 239 [2: 202]. Kant supposes there to be a problem, because what allows such a relation to be understood in the case of concepts - containment and the law of identity - makes it puzzling that we can understand it in the case of objects. $F R$ implies that there is no puzzle.

${ }^{19}$ Rudolf Haym, Arthur Schopenhauer (Berlin: Reimer, 1864), p. 84. Haym affirms, however, that what ultimately fuses these features together is something deeper.

${ }^{20}$ On the background to Schopenhauer's development, see Otto Weiß, Zur Genesis der Schopenhauerschen Metaphysik (Leipzig: Thomas, 1907), Arthur Hübscher, The Philosophy of Schopenhauer in its Intellectual Context: Thinker Against the Tide (Lewiston, NY: Mellon, 1989), and David Cartwright, Schopenhauer: A Biography (Cambridge: Cambridge University Press, 2010). A narrower focus is offered in Wilhelm Schröder, Beiträge zur Entwicklungsgeschichte der Philosophie Schopenhauers. Mit besonderer Berücksichtigung einiger wichtiger frühnachkantischer Philosophen (Maimon, Beck, G. E. Schulze, Bouterwek und Jacobi) (Rostock: 
Bold, 1911). Schröder sets against Schopenhauer's own claim that his philosophy sprang whole from his head like Minerva, the charge made by several critics that it is almost entirely 'borrowed': Volkelt and von Hartmann point to sources in the Vedanta, Eleatics, Scotus, Bruno, Spinoza, and Schelling; Seydel describes Schopenhauer's philosophy as corresponding to one stage of Fichteanism and the doctrine of objectification of the will as Hegelian; Windelband considers that Schopenhauer merely rearranges pieces from Kant, Fichte, and Schelling. Schröder's own thesis is that Schopenhauer takes his Kant critique and subject-object correlationism (without acknowledgement) from Schulze, Bouterwek and Jacobi, in opposition to the intellectualist postKantian trajectory represented by Maimon and Beck which leads to Fichte. My highlighting of Maimon below, as a resource for Schopenhauer's abreaction to intellectualism, is of course consistent with this.

${ }^{21}$ A. W. Moore, The Evolution of Modern Metaphysics: Making Sense of Things (Cambridge: Cambridge University Press, 2012).

${ }^{22}$ A. W. Moore, Points of View (Oxford: Oxford University Press, 1997), pp. 119-120; see also pp. $112-113$ and $125-126$.

23 'Transcendental Idealism at the Limit: On A. W. Moore's Criticism of Kant', Philosophical Topics, forthcoming 2016.

${ }^{24}$ We find a clear illustration in Maimon's Versuch einer neuen Logik oder Theorie des Denkens, nebst angehängten Briefen des Philateles an Aenesidemus (Berlin: Felisch, 1794), p. 134: given two drops of water indistinguishable by their concepts and distinguished only by their external relations, it is to be inferred by the PSR that their concepts are inadequate.

25 The task of transcendental logic for Maimon is to demonstrate the existence of 'reale Denken', as he believes Kant fails to do. Schopenhauer disposes of it by reducing transcendental knowledge to immediate awareness of the given fact of certain a priori necessities. Other important elements in Schopenhauer's philosophy can be related back to Maimon. Maimon assimilates space and time to the categories - they become Verstandesbegriffe - thereby removing the gap between intuition and conceptuality; they are, for Maimon, Fiktionen, in parallel with the essentially illusory spatiotemporal world in Schopenhauer. Second, Maimon's rejection of Kant's Antinomies of Pure Reason, on the grounds that their theses are meaningless, is replicated in Schopenhauer. Third, Maimon reduces general logic to transcendental logic (this is central to both of the Maimon texts that Schopenhauer is known to have read), which for Schopenhauer eliminates a further ground for thinking that there is such thing as reason outside the world as representation or as distinct from the PSR: see the section on metalogical truth, $F R, \S 33$, where Schopenhauer tells us that the nontranscendental laws of thought, inclusive of the Principles of Non-Contradiction and the Excluded 
Middle, share the epistemology of the PRS, namely immediate experience of repugnance of their contradictories, and have the same root. With regard to their attitudes towards the PSR, we find the following neat inversion: in Maimon's combination of rationalism and skepticism, a rational Real stands opposed to an irrational Given; in Schopenhauer's anti-rationalist and non-skeptical system, a rational Given is opposed to an irrational Real.

${ }^{26} M R$, Vol. 2, pp. 417-425.

${ }^{27} M R$, Vol. 2, pp. 353-355, 371-378, 389-391.

${ }^{28}$ Philosophical Investigations into the Essence of Human Freedom and Matters Connected Therewith, trans. Jeff Love and Johannes Schmidt (Albany, NY: State University of New York Press, 2006), p. 40. Schopenhauer's deep but disavowed debt to Schelling was remarked upon long ago: see Haym, Arthur Schopenhauer, pp. 83-84, and Otto Liebmann, Kant und die Epigonen. Eine kritische Abhandlung (Stuttgart: Schober, 1865), pp. 187-189.

${ }^{29}$ Philosophical Letters on Dogmatism and Criticism (1795), in The Unconditional in Human Knowledge: Four Early Essays 1794-1796, ed. Fritz Marti (Lewisburg: Bucknell University Press, 1980), p. 163.

${ }^{30}$ E.g., What Real Progress has Metaphysics Made in Germany Since the Time of Leibniz and Wolff? (1793), in Theoretical Writings After 1781, trans. Gary Hatfield et al, ed. Henry Allison (Cambridge: Cambridge University Press), p. 370 [20: 280].

${ }^{31}$ Schopenhauer makes use of this notion in his treatment of music (WWR1, §52), but notes its limitations (WWR1, 284 [303]).

${ }^{32}$ Liebmann notes the problem, Kant und die Epigonen, p. 200.

${ }^{33}$ Schopenhauer was aware of the issue: see, e.g., $M R$, Vol. 1, 373.

34 The option is explored and defended by G. Stephen Neeley, 'Schopenhauer and the Limits of Language', Idealistic Studies, 27, 1997, 47-67, taking off from remarks in F. C. White, On Schopenhauer's Fourfold Root of the Principle of Sufficient Reason (New York: Brill, 1992), pp. 58-59. Aestheticist construals of Schopenhauer's metaphilosophy are developed in Sandra Shapshay, 'Poetic Intuition and the Bounds of Sense: Metaphor and Metonymy in Schopenhauer's Philosophy', European Journal of Philosophy, 16, no. 2, 2008, 211-229, and Sophia Vasalou, Schopenhauer and the Aesthetic Standpoint: Philosophy as a Practice of the Sublime (Cambridge: Cambridge University Press, 2013).

${ }^{35}$ In this phenomenological respect (though of course in no other) they bear comparison with Kant's Fact of Reason.

${ }^{36}$ To describe Schopenhauer's conception of the aim of philosophy as therapeutic, though tempting, would give a misleading suggestion of instrumentality: Schopenhauer considers that philosophy 
serves its true purpose when it cancels the putative purposiveness of empirical consciousness, which it can do only if the vision or 'image' it sets before us, is intuited in the same way that we apprehend a work of art, as simply 'there for its own sake' (hence the scope, exploited by Hartmann, for representing philosophical insight as achieved on behalf of the world). The aim of philosophical reflection is therefore to reach a point which cannot properly be brought under either explanatory or instrumental categories, and once the system of philosophy achieves total completeness it melts back into the 'single thought' from which, Schopenhauer tells us, his system was born (WWRl, 5 [vii-viii]). In $M R$, Vol. 2, 412, Fichte is criticized for regarding philosophy as 'the art of explaining the world, like any instrument', and in the 1820 lectures we find: 'Die ganze Aufgabe der Philosophie wird erst deutlich, durch ihre Auflösung selbst' (Vorlesung über die gesammte Philosophie d.i. Die Lehre vom Wesen der Welt und von dem menschlichen Geiste. In vier Theilen. Erster Theil: Theorie des gesammten Vorstellen, Denkens und Erkennens, in Theorie des gesammten Vorstellens, Denkens und Erkennens. Aus dem handschriftlichen Nachlaß, ed. Volker Spierling (München: Piper, 1986), p. 572.

${ }^{37}$ See Eduard Zeller, Geschichte der deutschen Philosophie seit Leibniz, 2nd edn. (München: Oldenbourg, 1873), pp. 702-719, and Kuno Fischer, Geschichte der neuern Philosophie, Vol. 9, Schopenhauers Leben, Werke und Lehre (Heidelberg: Winter, 1897), Ch. 21. A sizeable list can be gleaned from Ueberweg's History of Philosophy. More recently, see G. Stephen Neeley, 'The Consistency of Schopenhauer's Metaphysics', in Bart Vandenabeele (ed.), A Companion to Schopenhauer (Oxford: Blackwell, 2012), pp. 105-119. 